The Survey continued to be represented in the working group drawing up regulations to govern the activities of companies undertaking mineral exploration on land in Greenland and in adjacent marine areas. This group completed in 1975 regulations for exploration work in marine areas and supplied the draft material for 'Offshore drilling regulations' published by the Ministry for Greenland in March 1976.

\title{
Physiographic and geological mapping of the sea-floor off West Greenland
}

\author{
Miodrag M. Roksandic
}

Part of the continental shelf off West Greenland between $61^{\circ}$ and $64^{\circ} \mathrm{N}$ was mapped in 1975. For this, data were drawn from three main sources.

(1) Newly published bathymetric maps covering offshore West Greenland from $59^{\circ} \mathrm{N}$ to $69^{\circ} 30^{\prime} \mathrm{N}$, with $10 \mathrm{~m}$ contour interval (Henderson, 1975) give a detailed picture of the sea-floor.

(2) The original echograms recorded by the Royal Danish Hydrographic Office give a more detailed picture of the relief along selected lines than can be obtained from (1) as well as giving indications of the nature of the sea-floor. Copies of echograms have been obtained from the Hydrographic Office, but the interpretation of these is at an early stage.

(3) Some sparker seismic profiles acquired in 1970 by Greenland Exploration Management Company, Inc. were studied to allow identification of units immediately below the sea-floor. The author wishes to thank the company for permission to refer in general terms to some of the main results stemming from this interpretation.

This brief report comprises general conclusions based on interpretation of data from all three sources, including the seismic data.

\section{Types of sea-floor}

Bathymetric data (Holtedahl, 1970; Henderson, 1975) enable four main types of physiographic units to be recognised:

(a) a very rugged inner part - strandflat,

(b) fairly flat banks on the outer side,

(c) marginal channels separating the banks from the strandflat and being roughly parallel to the coastline, and

(d) transverse channels lying between the banks.

The marginal channels, although very marked features, are not always the largest and/or deepest channels and numerous channels within the strandflat may exceed them in size. The

Fig. 9. Map showing petroleum concessions in the marine areas off part of West Greenland. The $500 \mathrm{~m}$ bathymetric contour is indicated. 
transverse channels have, as all glaciated valleys, very irregular longitudinal profiles, while the cross profiles can be rather variable, sometimes U-shaped, sometimes asymmetrical and irregular. It seems that thresholds are made of acoustically hard rocks, i.e. not of glacial deposits.

In addition to those features which are easily recognisable on the bathymetric maps many other forms characterising the sea-floor can be seen on both the seismic sections and echograms. Because of their dimensions, only the largest of them could be plotted on existing bathymetric maps.

Six types of sea-bottom can be distinguished. Criteria for classification of different types are wave-lengths and amplitudes of forms of relief, their shape and mutual relations.

Type 1 is characterised by very uneven sea-floor consisting of numerous features such as highs, channels, lows, etc. Wave-lengths vary very much from a few hundred metres to several thousand metres, but most frequently between $500 \mathrm{~m}$ and $2500 \mathrm{~m}$. Variations of amplitudes are also very high, from a few metres to several hundred metres, but usually less than $200 \mathrm{~m}$. Forms of relief show a tendency to be roughly parallel to the coast line. Type 1 is restricted to the inner part of the continental shelf and corresponds to the area where basement rocks occur with or without a very thin cover of recent sediments.

Type 2 is characterised by relatively high relief, amplitudes usually ranging up to $20 \mathrm{~m}$, and in some places even more. Wave-lengths are usually between 200 and $2000 \mathrm{~m}$, but may exceed this in places. Some features are asymmetrical. Locally a higher frequency microrelief (of wave-length usually less than $300 \mathrm{~m}$ and amplitudes up to $6 \mathrm{~m}$ ) is superimposed on it.

Interpretation of type 2 is somewhat problematical. Certain similarity between the types 1 and 2 suggests that they may have a similar origin. Type 1 is believed to be due to the glacial erosion. If so, type 2 might have originated by glacial erosion in the areas made of sedimentary rocks. It seems that sea-bottom of type 2 has not a continuous cover of Holocene sediments and may contain outcrops of older rocks.

Type 3 is characterised by high frequency relief with wave-lengths from less than $50 \mathrm{~m}$ (not measurable on the seismic sections) to $300 \mathrm{~m}$, sometimes even more, while the amplitudes usually range up to $6 \mathrm{~m}$, rarely more. In the studied area this type of sea-bottom has mostly been found, although not exclusively, in the channels.

King (1967) found a similar type of sea-bottom on the Scotian Shelf. Correlating it with the data from textural analyses of sea-bottom samples he determined that the above mentioned type corresponds to glacial till. The glacial till proved to be made up of on average $3 \%$ of gravel, $64 \%$ of sand, $17 \%$ of silt and $16 \%$ of clay. Shearer (1973) and Loring (1975) similarly interpreted sea-bottom of type 3 in the Gulf of St. Lawrence, Monahan \& Macnab (1975) found sea-bottom of the same type on the northern, eastern and western sides of the Flemish Gap and on the northern and eastern edge of the Grand Banks and reached similar conclusions. Shearer (1973) also pointed out that at depths less than $110 \mathrm{~m}$ irregular till surface has been reworked and smoothed.

It is concluded that in the study area, sea-bottom of type 3 probably corresponds mainly to glacial till.

Type 4 is flat, in some places with low undulations of relatively long wave-lengths.

In the area studied such a type of sea-floor exists on the banks and in some channels. On the banks it is often developed on the inner and the shallowest parts. 
According to Monahan \& Macnab (1975) the smoothness of the bottom "may indicate regions where sedimentary processes are or have been active". In all probability this is true for the channels, but on the banks this type of sea-bottom might also be a consequence of erosion by sea currents.

Type 5 may be considered as a transition between types 2,3 and 4. Amplitudes are small or moderate (usually not greater than $5 \mathrm{~m}$ ), while wave-lengths vary very much from being unmeasurable to more than $2000 \mathrm{~m}$. However, they are mostly between 300 and $1500 \mathrm{~m}$.

Sea-bottom of this type is widespread in the area under consideration. It is difficult to explain its origin because, in all probability, it may be of mixed kindred. One possibility is that it is the result of reworking of types 2 and 3, either by erosion or sedimentation.

Type 6 consists of graben-like lows, horst-like highs and stair-like features. Monahan \& Macnab (1975) found the same type of sea-bottom on the south-western corner of the Flemish Gap and described its surface as angular and blocky with deep and wide incisions. Type 6 , which seems to be of restricted extent, suggests a fault origin.

\section{Sub-bottom geology}

Seismic facies analysis makes it possible to recognise several stratigraphic units. In addition, older sedimentary rocks have been noticed in some channels, but it was not possible to infer their characteristics from the data studied. The substratum to all these sediments, the crystalline basement, outcrops in the strandflat.

\section{Post-glacial fill}

Some submarine channels and fjords, all of them glaciated valleys, are filled with a sequence characterised by an even layered, parallel reflection pattern. Reflections are usually continuous, but reflection amplitudes are changeable. Some events have high amplitude, the others moderate or low amplitudes. Lateral variations of amplitude are also noticeable, but only occasionally very conspicuous. As a rule, reflection frequency is high. It may be concluded that the sequence is a post-glacial, well-stratified sequence deposited in submarine channels and fjords. It is made up of lithologically different layers, some of them changing their characteristics laterally, but usually only slightly. In all probability the sequence is composed of clay, silt and sand.

In shallow parts the layers are parallel to the sea-bottom, i.e. almost horizontal. In some places the deepest part of the sequence may, be slightly undulating, with anticlines above ridges on the channels' bottom and synclines above lows. This undulation has been caused by compaction of sediments.

\section{Lateral moraine}

Lateral moraines have been revealed along some submarine channels. They are usually reflection free but in some places may have chaotic and/or a discontinuous reflection pattern. 
Ground moraine

In some transverse channels a sequence which is believed to be ground moraines has been found. This is a reflection free sequence except for some point reflections. Sea-bottom type 3 always corresponds to the ground moraines.

\section{Stratified outwash deposits}

On some banks and in some marginal and transverse channels a sequence, which is believed to be an outwash deposit, is developed. On the seismic sections, this sequence is represented usually by even layered, normally parallel but occasionally convergent reflection patterns. Reflection frequency is usually high, while amplitudes are moderate to high. In some places the existence of reflection free intercalations has been seen. The seismic signature indicates that the sequence is made up of stratified deposits with some intercalations of unstratified sediments.

On the banks the deposits discordantly overlie the older marine sediments, very often with an offlap. In the marginal channels the sequence covers with an onlap the basement rocks. In transverse channels and their sides the outwash has been partly removed by erosion and afterwards locally covered by moraines.

The outwash deposits dip, without exception, towards the neighbouring channels; the dip being usually less than $2^{\circ}$. This dip is believed to be a primary, sedimentary feature.

All available data suggest that the sequence was laid down in a water environment in the immediate vicinity of the ice margin. The retreat of the ice margin caused the change in the position of the sedimentary basin now marked by the offlap on the banks and by the onlap on the east-north-east. Afterwards the sequence was partly removed by glacial erosion in the transverse channel and covered by moraine.

Such an interpretation has two implications:

(1) the axis of the marginal channel migrated east-north-eastward during the deposition of the outwash deposits, and,

(2) the transverse channel existed during the deposition of the outwash deposits, but afterwards was deepened.

Pre-glacial fluvial sediments

At one locality a compound channel-like feature incised into the older rocks has been noticed. At least two or three river channels with different fills could be recognised, but most of the area seems to be made up of flood plain or delta fringe deposits.

\section{Marine(?) stratified deposits}

On seismic sections these beds are characterised by an even layered, parallel, continuous reflection pattern with variable, often high amplitude and usually high reflection frequency. This sequence is overlain by the outwash deposits or the pre-glacial fluvial sediments, but it 
can crop out as well or be covered only by a thin veneer of recent sediments. Generally it dips gently towards the sea.

The described unit is a stratified sedimentary sequence laid down in a depositional basin which was much larger than the basin of the outwash deposits. It may be of marine origin.

\section{Additional data}

Of the other data noticed on seismic sections two features are worth mentioning here.

(1) At two places along the studied lines mud mounds have been noticed on small faults. Such mud mounds have been interpreted as gas seeps (Antoine, 1975). However, seismic data cannot indicate the mode of formation or nature of the gas.

(2) On flanks of some marginal channels some features occur which judging from their forms could be slumps. On other places the outwash deposits are absent although they are developed in the neighbouring channel and bank. This might also be a result of slumping. Judging from the available data the slumping can occur on the slopes with an inclination greater than $5-6^{\circ}$.

\section{References}

Antoine, J. W. 1975: Advances in the interpretation of high resolution seismic data. Proc. 1975 Offshore Technology Conference, Houston 1, 313-320.

Henderson, G. 1969: Oil and gas prospects in the Cretaceous-Tertiary basin of West Greenland. Rapp. Grønlands geol. Unders. 22, 29-37.

Henderson, G. 1975: New bathymetric maps covering offshore West Greenland 59 $-69^{\circ} 30^{\prime}$ N. Proc. 1975 Offshore Technology Conference, Houston 1, 761-773.

Holtedahl, O. 1970: On the morphology of the West Greenland shelf with general remarks on the 'marginal channel' problem. Marine Geol. 8, 155-172.

King, L. H. 1967: Use of a conventional echo-sounder and textural analyses in delineating sedimentary facies: Scotian shelf. Can. J. Earth Sci. 4, 691-708.

Loring, D. H. 1975: Surficial geology of the Gulf of St. Lawrence.Pap. geol. Surv. Can. 74-30,2, 11-34.

Monahan, D. \& Macnab, R. F. 1975: Macro- and meso-morphology of Flemish Pass, and the northeastern Grand Banks of Newfoundland. Pap. geol. Surv. Can. 74-30,2, 207-216.

Shaerer, J. M. 1973: Bedrock and surficial geology of the northern Gulf of St. Lawrence as interpreted from continuous seismic reflection profiles. Pap. geol. Surv. Can. 71-23, 285-303. 